\title{
Environmental Policy Integration in Ukraine and the EU
}

\author{
Liudmyla Golovko ${ }^{1}$, Olena Yara ${ }^{2}$, Maksym Kutsevych $^{3}$ and Tamara Hubanova ${ }^{4}$
}

\begin{abstract}
The purpose of our scholarly work is to explore actual problems of harmonization of legislation of Ukraine in the sphere of environmental policy integration with EU law and development of proposals for the improvement of Ukrainian legislation. The state of environmental policy integration in Ukraine was assessed. Government strategies, programmes, concepts and plans in Ukraine and EU were analyzed. Based on comparison analysis differences and common problems of environmental policy integration in Ukraine and EU member states were determined and recommendations on the measures to be taken to ensure better integration of environmental policies in sectoral policies in Ukraine were made.
\end{abstract}

Keywords: environmental policy integration, sustainable development, strategic environmental assessment

\section{State of the Environment in Ukraine: Challenges for the Future}

Ukraine occupies one of the leading places in the world in terms of consumption of water, energy and other resources per unit of GDP. Industrial waste per capita in Ukraine exceeds similar indicators in many countries of the world. As a result of large-scale extensive exploitation over a long historical period, the natural resources of Ukraine are largely depleted and degraded. It concerns first of all land, water and forest resources.

About $40 \%$ of cultivated land suffers from erosion. Over the past 30 years, humus content in soils has decreased by 30\%. Greater damage to soils is caused by mineral fertilizers, chemical plant protection products, non-compliance with crop rotation, imperfect machinery and technology for cultivating land and agricultural production, open exploration of minerals (Maksiuta, 2017).

Ukrainian forestry is in the state of ecological imbalance. Many of the most important elements of forestry, including the forest management, forest inventory, protection of forests, reforestation, and protective afforestation are at a low level. There is a tendency for increase in deforestation. According to former Minister of Ecology and Natural Resources of Ukraine Sergiy Kurykin, the volume of illegal logging in Ukraine today is about $75 \%$. These figures are confirmed by official statistical data on timber exports to the EU. Moreover, environmentalists are concerned not so much with the increase in the amount of wood harvesting, as the fact that in the Carpathians concentrated cutting is

\footnotetext{
${ }^{1} \mathrm{PhD}$., associate professor of the Department of International Law and Comparative Law of the National University of Life and Environmental Sciences of Ukraine

${ }^{2} \mathrm{PhD}$, professor of the Department of Administrative and Financial Law of the National University of Life and Environmental Sciences of Ukraine, Dean of the Faculty of Law of the National University of Life and Environmental Sciences of Ukraine

3Doctor of Juridical Science, associate professor, deputy dean of the Faculty of Law and associate professor of the Department of Criminal Law and Criminology of the Faculty of Law of Taras Shevchenko National University of Kyiv

${ }^{4}$ Doctor of Juridical Science, associate professor, honored lawyer of Ukraine, director of Private Higher Educational Institution "Financial-Legal College"
} 
carried out on separate territories. This environmental problem causes flooding, changes in the microclimate, etc. (Ukrainian ecological organization, 2018).

Environmentally unbalanced economic activities that use significant water resources for the needs of the production sector and cause water pollution, artificial alteration of natural regime of water objects led to degradation processes that began to prevail over self-renewable and self-cleaning ability of water systems. Ukraine belongs to countries with relatively low water resources. The average perennial renewable volume of surface water is approximately $95 \mathrm{~km} 3$ per year, which is equivalent to 2,0 thousand $\mathrm{m} 3$ per person. In the low-water years the average perennial renewable volume of surface water is approximately 1.2 thousand $\mathrm{m} 3$ per person, which characterizes Ukraine as a water insecure country (Yara et al., 2017). It is also worth noting that tax revenues in the country's budget do not cover the necessary funds for the protection and reproduction of natural resources.

The state of the environment in Ukraine is a consequence of long-term economic activity without taking into account environmental requirements. That is why environmental policy integration into other policy areas is one of the most important tasks of the present.

\section{Strategic Directions for Adaptation of Ukrainian Legislation on EPI to the EU Standards}

Today, Ukraine's cooperation with the European Union and in particular in the field of environmental protection is carried out within the framework of implementation of the EU-Ukraine Association Agenda. According to article 363 of the Association Agreement between the European Union and the European Atomic Energy Community and their member states, of the one part, and Ukraine, of the other part, gradual approximation of Ukrainian legislation to EU law and policy on environment shall proceed in accordance with Annex XXX to this Agreement. According to this Annex Ukraine undertakes to gradually approximate its legislation to 29 Directives and Regulations within the stipulated time frames in such sectors: environmental governance and environmental policy integration into other policy areas; air quality; waste and resource management; water quality and water resource management, including marine environment; nature protection; industrial pollution and industrial hazards; climate change and protection of the ozone layer; genetically modified organisms. In order to fulfill these tasks Ukraine has adopted a number of regulations aimed at organizational and legal support for this process.

In the field of environmental policy integration into other sectoral policies four EU horizontal directives require implementation: Directive 2001/42/EC of the European Parliament and of the Council of 27 June 2001 on the assessment of the effects of certain plans and programmes on the environment, Directive 2011/92/EU of the European Parliament and of the Council of 13 December 2011 on the assessment of the effects of certain public and private projects on the environment, Directive 2003/35/EC of the European Parliament and of the Council of 26 May 2003 providing for public participation in respect of the drawing up of certain plans and programmes relating to the environment and Directive 2003/4/EC of the European Parliament and of the 
Council of 28 January 2003 on public access to environmental information.

Environmental policy integration refers to the incorporation of environmental concerns into sectoral policies in order to reduce policy incoherence and achieve synergies to more effectively address environmental problems such as environmental degradation. Environmental policy integration should aim to

- achieve sustainable development and prevent environmental damage

- remove contradiction between policies as well as within policies

- realise mutual benefits and the goal of making policies mutually supportive (Lafferty, 2002).

On December 18, 2017, the Law of Ukraine "On Environmental Impact Assessment" came into force. Environmental impact assessment is a legal instrument for the prevention of harmful effects of projects on the environment. New normative legal act is more modern and closer to European standards. Previously, the environmental impact assessment was regulated by Laws "On Environmental Protection" and "On Ecological Expertise". The main disadvantage was that the assessment took place at the level of construction contracts. Accordingly, other activities that may affect the environment, for example, tree felling, change of land use, were not considered. It is important that now in Ukraine environmental impact assessment is carried out before starting a project, and not at approval stage as it was before.

Another innovation is that the public has been given the right to timely, adequate and effective information in the process of environmental impact assessment. That is, all information about the planned activities of enterprises is open. Access to the information, including quantitative and qualitative indicators of waste and emissions, making copies (photocopies) can not be limited. Citizens can also submit any comments and proposals without the need for their justification. This can be done either in writing or electronically, and during public hearings.

At the same time, despite the fact that the introduction of a new procedure for environmental impact assessment is intended to make the environmental impact assessment process more transparent and efficient, it has several shortcomings. The procedure for assessing the environmental impact, based on the number of its stages and the terms of their execution, will take about 4-8 months. The number of stages for obtaining an opinion on environmental impact assessment makes this procedure complicated and too long, which can have a negative impact on economic activity. Besides, unfortunately, the effect of new law does not apply to already existing business entities that previously received permits for their activities and now pollute the environment.

On October 1, 2018 the Law "On Strategic Environmental Assessment" came into force. It is an important step forward in Ukrainian environmental law. In general, the Law is in line with the Strategic Environmental Assessment Directive. But, the law does not provide for an assessment of the effectiveness in the execution of state strategic planning documents. Such an assessment should be foreseen. In addition, civil society representatives should be involved in the assessment. The assessment should also foresee the identification of the reasons hindering the achievement of the goal and the implementation of tasks, the development of decisions on changes in activities for the implementation of strategic plans, their goals and objectives. Ukrainian legislation does 
not contain mechanisms for taking environmental considerations into account when developing state planning documents.

According to experts, strategic environmental assessment in Ukraine is still nonsystematic and sometimes has only formal nature. Taking into account that the formal requirements of the strategic environmental assessment specified in the Law of Ukraine "On Strategic Environmental Assessment" are not an absolute guarantee for establishing the strategic environmental assessment practice and do not necessarily guarantee that the strategic environmental assessment will be effectively applied, development of effective mechanisms of its conduct is necessary, in particular methodological tools for the implementation of the provisions of this Law, which will enable the integration of environmental initiatives in the planning process at appropriate levels (Kozachenko, 2018). On the example of European Union a handbook on environmental assessment of regional development programmes should be developed.

Unlike the EU, in Ukraine ecologization of sectoral policies is limited. The integration of the ecological component into sectoral development programs is inadequate and inappropriate because:

- in the current legislation there are no rules concerning ecologization of production;

- long-term strategies and programs for integration of environmental policy into sectoral policies are not yet being developed;

- promotion and incentives for producers to introduce environmentally friendly production is insufficient;

- state support for the implementation of environmental measures, even if they are provided for by the state and sectoral programs and plans is limited.

At the institutional level, there is no government agency that would coordinate the integration of the environmental component in all sectors of the economy and public life.

At the regional level, strategic and program documents are not always consistent with national programs and strategies, are not effective and are insufficiently funded. The authorities do not want or can not take into account the ecological component in the plans of social and economic development of cities as an integral part of development plans. Plans for the socio-economic development of cities should include an environmental section.

To ensure the implementation of European environmental standards in the sphere of environmental policy integration into Ukrainian legislation just adoption of laws is not enough. For implementation it is also necessary to ensure the availability of appropriate institutions and budgets for the implementation of these laws and other normative legal acts. Also it is necessary to create an effective system of monitoring and sanctions in order to insure that requirements of the laws are implemented completely and appropriately (Ladychenko, 2017).

\section{Positive EU Experience, which Should Be Implemented in Ukraine}

Environmental policy integration has been broadly embraced as a principle in European policy making (Nilsson, 2003). In one sense, the EU did make a forceful move to implement environmental policy integration by enshrining a quasi-constitutional 
commitment in its funding treaties in 1996 in order to achieve greater legal clarity and hence enforceability. Around this time many states and the EU adopted some of the policy instruments explicitly mentioned by Brundtland, namely green budgeting, integrated policy appraisal, impact assessment (Russel, 2009).

In our opinion, in Ukraine on the EU example should be used such instrument as green budgeting. Green budgeting, understood as in-depth environmental evaluation as part of the annual budgeting procedure, can reveal spending that is contradictory to environmental objectives. By highlighting environmentally harmful spending and offering alternatives by, for example, shifting resources to more environmental-friendly policies and programmes it represents a strong political commitment to improving the environmental performance of all departments (Jacob et al., 2008).

In a more recent development, EU financial support for regional and agricultural projects was tied to adequate compliance with the Habitat, Nitrates and Birds Directives (this conditionality is known as "cross-compliance"). From 2000, approval of structural funding was made contingent upon adequate implementation of the Habitat and Birds Directives. This was subsequently extended to agricultural spending under the Rural Development Regulation (Jordan, 2013).

Another instruments that proved its effectiveness in the EU member states and which it is useful to implement in Ukraine are Environmental Management Systems (EMSs). EMSs are designed to encourage industry to behave in a more environmentally responsible manner and are defined as "a formal set of procedures and policies that determine how an organisation will manage its potential impacts on the natural environment and on the health and welfare of the people who depend on it". Like voluntary agreements, EMSs focus on integrating environmental concerns at the company level, though their relationship with government policies is more remote. Although the precise characteristics of different EMSs differ, in general they create a system to audit the environmental impact of activities throughout an entire company. Their goal is to assist organisations to ensure that their operations comply with environmental regulations and further that major environmental risks, liabilities and impacts are identified, minimised and managed (Darnell et al., 2000). There are no classifications of the main types of EMSs but the two most popular and well known are the global ISO 14001 and the EU Environmental Management Audit Scheme (EMAS). The EU attempts to promote voluntary instruments like the European eco-label, the Environmental management and audit system (EMAS), technical standardisation or voluntary agreements. These instruments suffer from the weakness that they leave all freedom to business to decide and little obligation to deliver. Nevertheless, EMAS and technical standardisation are used increasingly as implementation tools for environmental legislation (Scheuer, 2005).

Although participation in EMSs is voluntary, once a company has decided to register with an EMS it must follow all its provisions (Watzold et al., 2001). Participation in EMSs schemes has obvious costs for the companies but it can also lead to cost savings and corporate benefits, can increase consumer and investor confidence in the company, promote competitive advantage, can promote cost savings through higher energy efficiency, thereby linking environmental concerns to economic benefits (Herodes, 2007). 
Unfortunately, today in Ukraine environmental auditing is not developed in both public and private sector. Only $7-8 \%$ of enterprises prepare and publish a separate nonfinancial report, which also includes information on the impact of the enterprise on the environment. The main obstacles to the development of environmental audit in Ukraine are: imperfection of the regulatory framework in the field of eco-auditing and borrowing of foreign experience which is not always adapted to the realities of the country's economy; lack of awareness by the enterprise management of the benefits of EMAS for enterprises (increasing their competitiveness through higher consumer confidence; increasing the investment attractiveness of an enterprise through the possibility of successful international certification and promotion of environmental activities; obtaining additional profit as a result of more efficient use of limited natural resources in the production process, which leads to an increase in output; reduction of risk of manmade and environmental disasters leading to significant economic losses; prevention of payment of fines and penalties for improper payment of environmental taxes; reduction of the level of production of ecologically unsatisfactory products, reducing the negative impact on the environment and the health of staff) (Zholobchuk, 2013).

Public consultative boards as an external coordinating and communication instrument between the government agencies and society groups proved to be efficient mechanisms to advance participation and education components of the environmental communication cycle. Allocation of greater environmental communication responsibilities to the state agencies (like Latvian Nature Museum, Nature Protection Agency) demonstrates better results, as professional staff is involved in environmental communication planning and implementation (Lagzdina, 2010).

\section{Conclusions}

Political support of the environmental policy integration is strong in the EU. The main instruments for environmental policy integration are planning tools, environmental impact assessment, strategic environmental assessment, environmental management systems, market and economic instruments. European standards for environmental assessment require the establishment of clear and transparent environmental assessment procedures for decision-making by authorities regarding the sustainable development of the territories and production planning providing for public participation and taking into account existing and potential environmental problems.

Recently in Ukraine a lot of work was done to introduce environmental policy integration mostly recently with the goal to fulfill the obligations imposed in the Association Agreement. Over the last two years, the focus of the implementation process has been on the implementation of environmental impact assessment and strategic environmental assessment in Ukraine, which are important environmental policy tools that provide an opportunity to assess possible environmental damage and prevent or minimize it. At the same time the following policy instruments which were adopted in the EU and confirmed their effectiveness in practice should be introduced in Ukraine: green budgeting, policy coordination for the environment, environmental management and audit system. For the development of environmental auditing, it is necessary to improve the regulatory framework; popularize foreign and develop domestic principles 
for conducting an eco-audit of enterprises; introduce a national system of marking and certification of products that have undergone an environmental inspection.

\section{References}

Darnell, N., Gallagher, D., Andrews, R., Amaral, D. (2000). Environmental Management Systems: Opportunities for improved environmental and business strategy? Environmental Quality Management, 9(3), 1-9.

Herodes, M., Adelle, C., Pallemaerts, M. (2007). Environmental Policy Integration and Modes of Governance - A literature review, EPIGOV Paper № 3, Ecologic - Institute for International and European Environmental Policy: Berlin.

Jacob K, Volkery A, Lenschow A. (2008). Instruments for environmental policy integration in 30 OECD countries. In Innovation in Environmental Policy? Jordan A, Lenschow A (eds). Elgar: Cheltenham; 24-48.

Jordan, A., Adelle, C. (2013). Environmental Policy in the EU Actors, Institutions and process. Third edition. Abingdon: Routledge

Jordan, A., Lenschow, A. (2010). Policy Paper Environmental Policy Integration: a State of the Art Review. Environmental Policy and Governance, 20, 147-158

Kozachenko, T. (2018). Strategic Environmental Assessment in Ukraine: Problems and Prospects. Investments: practice and experience, 16, 98-101.

Ladychenko, V., Golovko, L. (2017). Implementation of European Environmental Policy in Ukraine: Problems and Prospects. European Journal of Sustainable Development, Volume 6, № 3, 333-339

Lafferty W.M., Hovden E. (2002). Report № 7/02 Environmental Policy Integration: Towards an Analytical Framework? Retrieved from: http://www.prosus.org/prosusFTP/prosusrep/publications /prosusrep2002 07.pdf

Lagzdina, E. (2010). Environmental Communication Instruments for Environmental Policy Integration. Scientific Journal of Riga Technical University, Volume 5, 56-64.

Maksiuta A. (2017). Analysis of the state strategic documents of Ukraine regarding the accounting of the Sustainable Development Goals until 2030 adapted for Ukraine: Analytical report. Moscow: Institute of SocioEconomic Research.

Nilsson, M. Persson, A.(2003) Framework for analysing environmental policy integration. Journal of Environmental Policy and Planning, 5(4), 333-359.

Russel D, Jordan A. (2009). Joining up or pulling apart? The use of appraisal to coordinate policy making for sustainable development. Environment and Planning, 41(5), 1201-1216.

Scheuer, S. (2005). EU Environmental Policy Handbook. A Critical Analysis of EU Environmental Legislation. European Environmental Bureau. Retrieved from: http://www.wecf.eu/cms/download/20042005/EEB Book.pdf

Ukrainian ecological organization. (2018). Ukraine annually sells more than 1 million cubic meters of smuggled wood Green world, 339, 4-5. Retrieved from: http://www.zelenysvit.org.ua/np/zelenysvit 339.pdf

Wätzold, F., Bültman, A., Eames, M., Lulofs, K., Schucht S. (2001). EMAS and regulatory relief in Europe: lessons from national experience. Environmental policy and governance, Volume 11, Issue 1, 37-48.

Yara, O., Uliutina, O., Golovko, L., Andrushchenko, L. (2018). The EU Water Framework Directive: Challenges and Prospects for Implementation in Ukraine. European Journal of Sustainable development, Volume 7, № 2, 175-182

Zholobchuk, I. (2013). Environmental audit in Ukraine problems and relevance of implementation. Bulletin of Taras Shevchenko National University of Kyiv, 144, 60-63. 